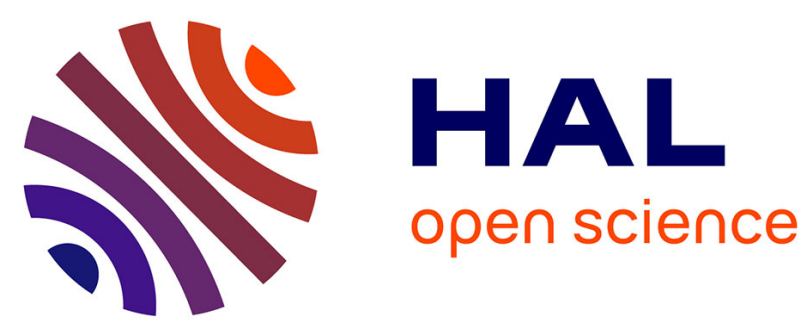

\title{
Past and present of a Mediterranean small-scale fishery: the Greek sponge fishery-its resilience and sustainability
}

Maïa Fourt, Daniel Faget, Thanos Dailianis, Drosos Koutsoubas, Thierry

Perez

\section{- To cite this version:}

Maïa Fourt, Daniel Faget, Thanos Dailianis, Drosos Koutsoubas, Thierry Perez. Past and present of a Mediterranean small-scale fishery: the Greek sponge fishery-its resilience and sustainability. Regional Environmental Change, 2020, 20, pp.1. 10.1007/s10113-020-01581-1 . hal-02527243

\section{HAL Id: hal-02527243 \\ https://hal-amu.archives-ouvertes.fr/hal-02527243}

Submitted on 4 Dec 2020

HAL is a multi-disciplinary open access archive for the deposit and dissemination of scientific research documents, whether they are published or not. The documents may come from teaching and research institutions in France or abroad, or from public or private research centers.
L'archive ouverte pluridisciplinaire HAL, est destinée au dépôt et à la diffusion de documents scientifiques de niveau recherche, publiés ou non, émanant des établissements d'enseignement et de recherche français ou étrangers, des laboratoires publics ou privés. 


\title{
Past and Present of a Mediterranean small-scale fishery: the Greek sponge fishery, its resilience and sustainability
}

\author{
Authors \\ Maïa Fourt ${ }^{1 *}$, Daniel Faget ${ }^{2}$, Thanos Dailianis ${ }^{3}$, Drosos Koutsoubas ${ }^{4}$, Thierry Pérez ${ }^{1}$ \\ e-mails: maia.fourt@imbe.fr, daniel.faget@univ-amu.fr, thanosd@hcmr.fr, drosos@aegean.gr, \\ thierry.perez@imbe.fr \\ Affiliations \\ 1 Institut Méditerranéen de Biodiversité et d'Ecologie marine et continentale, Aix-Marseille \\ Université, UMR 7263 CNRS 7263, IRD 237, Station Marine d'Endoume, Rue de la Batterie des \\ Lions, 13007 Marseille, France. \\ ${ }^{2}$ Laboratoire TELEMME, Aix-Marseille Université, CNRS, Maison Méditerranéenne des Sciences \\ de l'Homme (MMSH), 5, rue du Château de l'horloge, BP 647, 13094 Aix-en-Provence, France. \\ ${ }^{3}$ Institute of Marine Biology, Biotechnology and Aquaculture, Hellenic Centre for Marine \\ Research, P.O. Box 2214, Heraklion 71003, Greece. \\ ${ }^{4}$ Department of Marine Sciences, University of the Aegean, University Hill, Mytilene 81100, \\ Lesvos, Greece.
}

*Corresponding author: Thierry.perez@imbe.fr tel: +33 (0)4 91041629

Number of words (not counting figures or the supplementary material): 5262

3 figures

\begin{abstract}
Global change impacts Mediterranean fisheries and the dependent human populations. Overfishing and epizootic diseases related to extreme climatic events are currently accepted as the main threats on the production of commercial bath sponges. Believing that other factors could have impacted this insular fishery, we assembled a 150 years long series of sponge fishing data for Greece that was analyzed in relation with variations of the pressure and of the socio-economic contexts. Sponge fishing experienced huge variations, with notably two distant short periods when the production collapsed (late 19th century and between 1985 and 1991). Before the 1970s, these variations are mainly attributed to socio-economic and political changes. The monitoring of the catches per unit effort indicates a clear overfishing impact only after 1977. However, after the last collapse of the overall production which followed the severe disease outbreak of the late 80's, the catch per unit effort showed a positive trend, which tends to indicate that the stocks available bear the present fishing pressure. Fishermen have adapted towards sustainable practices, by reducing their crew and also diversifying their targets, what nevertheless calls to a more accurate monitoring of such a small scale fishery.
\end{abstract}

Key-words: bath sponge, Mediterranean, historical trend, fishery, environmental changes 


\section{Introduction}

Global change affects the oceans and their ecosystems (Harley et al. 2006; Brierley and Kingsford 2009), therefore impacting their productivity and threatening fisheries and human societies (Cheung et al. 2013; Barange et al. 2014). The Mediterranean Sea is a miniature ocean and a hotspot of biodiversity providing a multitude of goods and services to the surrounding human societies (Coll et al. 2010). This sea has experienced different major sources of disturbance for several decades such as sea warming, changes in the thermohaline circulation, invasions by alien species (Lejeusne et al. 2010) as well as overfishing and habitat loss (Coll et al. 2010) . Mediterranean fisheries have therefore been documented to be impacted by climate change (Tzanatos et al. 2014), with indicators such as total catch, catch-based method, mean trophic level of the catch and fishing in balance index showing a particularly deteriorated situation in the Eastern basin (Tsikliras et al. 2015). The degree of vulnerability is critical for small-scale fisheries, the impact on dependent human populations being especially strong when they are insular (Maynou et al. 2013; Hanich et al. 2018). Although small-scale fisheries also often represent a substantial part of an island cultural heritage, they have rarely been studied. Indeed, fisheries reports and research studies consider mainly the large ichthyologic resources (e.g. Tzanatos et al. 2014; FAO 2016)). Benthic organisms, such as sponges, corals, tunicates, mollusks, crustaceans and echinoderms are known to be particularly vulnerable to environmental disturbances and anthropogenic pressures because of their habitats' proximity to human activities and their difficulty to move towards more favorable environmental conditions (Lejeusne et al. 2010).

Mediterranean commercial bath sponges occur in coastal benthic ecosystems down to $110 \mathrm{~m}$ depth (Pérez and Vacelet 2014). They are therefore particularly exposed to various anthropogenic pressures and extreme climatic events (Coll et al. 2010). Along with other sessile invertebrates, they have been recently affected by mass mortality events that are mainly attributed to climatic anomalies (Lejeusne et al. 2010). Therefore, we believe that sponge fisheries can represent an ideal model to study the effect of the global change. Various components may act on such a small-scale, insular socio-ecosystem, and we thus intended to assess the role of the geopolitical context, of the change of uses and of environmental changes.

In the Mediterranean Sea, six sponge species can be harvested and commercialized for their fiber skeleton. They are the target of traditional insular fishing communities using a variety of techniques either selective such as harpooning and diving or unselective such as dredging (Pronzato and Manconi 2008). The commercial sponge exploitation took off in the Mediterranean area during the 19th century in response to a high sponge demand by developing industries and new concerns for hygienic practices. Since then, the fishing techniques, the availability of the resources, the regulations, the political and economic contexts of the Mediterranean countries have greatly varied and have shaped a changing sponge industry through time and space. In 150 years, this fishery has undergone significant upheavals that have deeply affected the related human populations (fishermen, captains and traders). It remains nowadays a traditional small-scale fishery, strongly anchored in some Mediterranean populations, and there is a particularly lively cultural heritage in the Dodecanese islands of Greece, where sponges are harvested for commercial purposes since the Antiquity $^{1}$ ( Pronzato and Manconi 2008; Voultsiadou et al. 2011).

Mediterranean sponge beds have suffered overfishing together with devastating epizootic diseases related to extreme climatic events, the year 1986 representing a pivotal year for the fishery, as bath sponges experienced mass mortalities in most of the producing countries. The combination of these two stressors is currently accepted as the main explanation for a drastic reduction of the level of exploitation (Pronzato and Manconi 2008; Pérez and Vacelet 2014). In this study, we aim at assessing the relevance of this hypothesis by analyzing the longest and most complete historical

\footnotetext{
${ }^{1}$ Collecting sponges from the sea has been reported as a profession since the second century A.C. at least, when the poet Oppian mentions fishing in his poem Halieutica (book 5).
} 
data available of the Greek sponge fishery, in order to better understand the present situation and eventually identify other potential acting drivers.

\section{Materials and Methods}

Greek sponge fishermen use to harvest sponges thought-out the Mediterranean. Therefore their past production and exportation includes catches from the Aegean Sea but also off Tunisia, Libya, Syria, Egypt, Turkey and Cyprus depending on the periods.

Sponge exportation (1860-1929) and production (1930-2017) data, as well as sponge fleet and crew data have been collected in various archive sources. Because of the difficulty of finding these sources and the pertinent information within these sources, the archive references providing the raw data were listed in Online Resource 1. The data were collected from commercial, fisheries and general statistical reports, published by the Ministry of Finances of Greece, section 3 and 4 accessible through the Hellenic Statistical Authority, as well as from British Foreign Office reports. To supplement the lack of data before 1890, the quantities exported from Greece to Trieste were also considered. These data, extracted from reports issued by the Chamber of Commerce of Trieste, can be considered as a good approximation of the total exports from Greece since, in 1872 for example, 86\% of the exported Greek sponges passed through Trieste. The Food and Agriculture Organization of the United Nations (FAO) provided production values for the years 2008-2014 (FAO, 2018). Kalymnian Port Police provided production data for the years 2015-2017 and number of boats for the years 2009-2017. Olympitou (2014) and a regional activity report (report of the prefecture of the Dodecanese see Online Resources 1) provided point data. When an annual value could be obtained from more than one source, a mean value was computed. Overall, the collected data represent 233 records of annual tonnage associated to an evaluation of the fishing effort that came from 58 different documents stemming from 6 main archive sources. It enabled us to calculate two metrics of catch per unit effort (CPUE), the annual production by boat and that by fisherman. These two metrics can then be compared and their temporal evolution followed.

In addition, sound-recorded interviews were carried out with 12 sponge fishermen from Kalymnos Island (September, December 2017 and October 2018) and 3 from Limnos Island (June, 2018). The aim of these interviews was to better understand the fishery's present situation, to acquire knowledge on sponge distribution and fishing areas, to collect information on the changes that have occurred within the sponge population and the fishery during the last decades.

Long term series of the Eastern Mediterranean Sea temperature do not exist. Thus, sea surface temperature (SST) data of the Northern Hemisphere were downloaded from the Met Office Hadley Centre observation datasets (Kennedy et al. 2011a, 2011b; https://www.metoffice.gov.uk/hadobs/hadsst3). These data were retrieved from the International Comprehensive Ocean-Atmosphere Data Set (ICOADS) from 1860 to 2006 and from Global Telecommunication System (GTS) observations from 2007 onwards. Temperature data are herein presented as deviation (SST anomalies) of the observed SST from the Northern Hemisphere annual mean between 1961 and 1990.

All data and information collected were put together with corresponding references in a Microsoft Access relational database. This allows connections between socio-economic, political situations and change of the thermal regime, and also enables information cross-checking. Extractions of the database are available on demand. Figures were created with the RStudio freeware connected to the Access database.

\section{Results}

Since 1860, Northern Hemisphere SST anomalies have shown long time-scale oscillations (Fig. 1). Between 1860 and 1940, SST anomalies remained mainly negative and showed positive values only for the years $1868\left(+0.065^{\circ} \mathrm{C}\right), 1877\left(+0.139^{\circ} \mathrm{C}\right), 1878\left(+0.168^{\circ} \mathrm{C}\right)$ and $1937\left(+0.104^{\circ} \mathrm{C}\right)$, meaning that annual SSTs generally stayed lower than the mean 1961-1990 annual SSTs. Between 
1940 and 1970 , the SST anomalies fluctuated from $-0.109^{\circ} \mathrm{C}$ to $+0.195^{\circ} \mathrm{C}$ with a near zero anomaly $\left(+0,067^{\circ} \mathrm{C}\right)$ and low standard deviation $(0.076)$. Between 1971 and 1986, SST anomalies were mainly negative ranging from $-0.233^{\circ} \mathrm{C}$ to $+0.023^{\circ} \mathrm{C}$. Since 1987 , SSTs have always been higher than the mean $1961-1990 \mathrm{SST}$, and have shown a positive trend $\left(+0.19^{\circ} \mathrm{C}\right.$ per decade.year ${ }^{-1}$ between 1987 and 2017 see Fig. 1). Moreover, since 1997, SST anomalies have continuously been out of the 1860-1987 range.

Throughout the studied period, the Greek annual sponge production or exportation varied significantly from year to year (Fig. 1). An era of acute increase of sponge production was observed after the middle to the end of the $19^{\text {th }}$ century (1878-1888), when sponge exportation increased from 14 to 222 tons. Two maximum values were reached, one in 1888 with $222256 \mathrm{~kg}$ of bath sponges exported, and another in 1950 with $168960 \mathrm{~kg}$ produced. Both of these maximum values were followed by subsequent collapses. The first collapse occurred at the end of the 19th century, between 1888 and 1904, when Greek sponge production decreased over 95\% in 16 years. Sponge production remained relatively low for the following 35 years (1904 to 1939), averaging around 36 tons per year, while no evidence for sponge production was available between 1938 and 1947. Between 1939 and 1946, no sponge fishing can be recorded due to the Second World War, and this period was followed by a production enhancement. However, this boost was almost immediately followed by the second collapse, a persistent declining trend over the three subsequent decades, during which the production gradually decreased to a tenth of its post-war value in the 1980s (Fig. 2), and never exceeding $10000 \mathrm{~kg}$ per year since 1990.

After 1947, annual Greek sponge production, as well as the number of sponge fishing boats of the country, suffered a sharp decline in several stages (Fig. 2). Between 1950 and 1973 the Greek sponge production decreased over $70 \%$ in 23 years. After a period of slower decline, the production showed a decrease of over 92\% between 1985 and 1991. The fleet drastically reduced from 229 boats in 1949 to 5 in 2016. In parallel, the total annual catches collapsed from $168960 \mathrm{~kg}$ in 1950 to $2500 \mathrm{~kg}$ in 1991 and $1500 \mathrm{~kg}$ in 2016. However, in the 1970s, the production of the Greek seas stayed relatively stable for a decade (mean annual harvest between 1972 and 1979 was $46463 \pm$ $5385 \mathrm{~kg}$ ), comparable to that of the 1950s for the same fishing area (mean annual harvest in Greek seas of the only three years available 1948, 1955 and 1956, was $47638 \pm 13357 \mathrm{~kg}$ ). The variation in the number of boats closely matched the production fluctuations, except for the years 1977-1991. Between 1976 and 1977, the sponge fishing fleet rose from 60 to 83 boats. The fleet kept its size through the 1980s, when sponge production decreased and reached an all-time low, dropping below $10000 \mathrm{~kg}$. This situation led to a crash in 1992 when the number of boats was abruptly reduced from 71 to 11 within a year and the production stayed low.

The catch per unit effort (CPUE) can be considered by boat or by fisherman (Fig. 3) and both reveal different information depending on the period considered. Between 1948 and 1976, the annual production by boat fluctuated around a mean value of $780 \mathrm{~kg}$, but it first dropped between 1977 and 1986, with a mean production of $547 \mathrm{~kg}$. Between 1986 and 1991, the annual CPUEs showed a sharp negative trend and shrank to $35 \mathrm{~kg} /$ boat (Fig. 3), a critical point that led to a drastic reduction of the fleet size the following year (Fig. 2). As a consequence of the fleet collapse (Fig. 2), from 1992 on, the production by boat progressively increased, sometimes reaching values comparable to those of the 1960s, but with a high inter-annual variability. Before the 1980s, the annual production per fisherman varied little from year to year with a slight increasing trend (Fig. 3) and a maximal production reached in 1971 with over $200 \mathrm{~kg}$ per fisherman, more than twice that of 1948. After 1991, the ratio production by boat/production by fisherman appears considerably reduced, which is indicative of a significant reduction of the crew sizes. Catches by fisherman show strong interannual variations around a mean value of $209 \mathrm{~kg}$ per fisherman, some years surprisingly rising to values more than 4 times those of 1948 and equivalent to the highest catches by boat for the studied period (Fig. 3). After this peak in 2014, the value of the two metrics drop but they nevertheless remain twice as high as the first years of the studied period. 
The 15 interviews of sponge fishermen provided quite homogeneous answers. Nowadays, they belong to 10 to 15 fishing boats in Kalymnos and at least 2 in Limnos, all equipped with hookah diving system, the only technique that is presently used in Greece for sponge fishing. However, since 2000, less than 5 of these boats register yearly for sponge fishing in Kalymnos and none in Limnos. They declare that their mean production is about $200-250 \mathrm{~kg} / \mathrm{boat}$ by month, a value which is close to the official data found in the Kalymnian Port Police archives. According to these fishermen, sponges develop everywhere in the Greek seas, therefore they scatter all around but favor the areas of Crete and the North Aegean Sea that offer the best quality of sponge. They witness on the 1986 mass mortality, but also on other disease outbreaks which affected bath sponges in several places: in the NE Aegean in 1996, in Southern Greece affecting also other benthic species in 1999-2000, in Crete in 2005, in the Dodecanese, Peloponnese and the North Aegean in 20122013, in North Aegean in 2016, around Crete, the Dodecanese and Limnos (NE Aegean) in 2018. They declare that before 1986, mortality events were rare and sponge boats were able to harvest many more sponges than nowadays. These outbreaks always happen at the end of the summer. In their opinion, the sponge population had recovered as of before 1986, only between 1996 and 1999 and again between 2009 and 2012. They feel that the selection of their fishing area for a campaign has become a lottery since the local sponge populations may have been suffered a disease before their arrival. This puts them in a difficult financial situation, expenses having been incurred for no, or little income. If disease outbreaks didn't occur so frequently, they considered that one can make a good living from the activity, sponge prices being high. Nowadays, the sponge fishermen that have remained, counterbalance the irregular sponge stock availability due to epizootic events, by holothurian sponge fishing in the winter season. They generally programed two campaigns of 1.5 to 2 months between May and late October to collect sponges. However, very recently holothurian fishing ensuring a good revenue, many fishermen have reduced their sponge fishing campaigns to only one per year.

\section{Discussion}

The sponge "Golden Age" followed by a first downfall of the fishery

Over the studied period, the variations of the Greek sponge production can be assigned to different triggering factors. Before the middle of the 20th century many technological innovations, sociopolitical and economic changes took place, affecting considerably all components of the Greek sponge fishery (Biliotti 1873; Bernard 1976b). During the mid-19th century, the world demand in sponges increased considerably, especially in industrialized countries (Bernard 1976a) such as the UK, France, Germany and the United States. In this context of an increasing demand, more efficient production methods were searched for, and technological progress enabled after 1865, the implementation of a surface air delivery system, the hard-hat equipment. This method rapidly spread, allowing sponge divers to remain considerably longer underwater. A French sponge merchant P. Aublé ${ }^{2}$ indicated that this new method was at least twice more efficient in harvesting sponges than the best unequipped divers. Therefore, although this new imported technology was very costly, investments for campaigns to the sponge-rich North-African coasts were easily found and Greek production rapidly increased.

Worries for the sponge stocks had been expressed before the introduction of the hard-hat equipment (Henrichs, 1836; Blondel 1840), but the extensive use of this new method nevertheless led to overexploitation of sponge beds (Holmwood 1890; Caravokyros 1895). However, the exportation decline recorded between 1889 and the beginning of the 20th century must be attributed to a complex of factors, economic aspects being the motor of production. The economic depression affecting the sponge-importing countries that occurred in the 1880's, started by decelerating all Greek exportations (Petmezas 2013). Following that period, Greece itself went through an

\footnotetext{
${ }^{2}$ In 1867, P. Aublé wrote 63 pages on sponge fishing in Rhodes island which has never been published, however the draft manuscript can be found in the municipal library of Saint Raphael, France
} 
important economic crisis starting in the early 1890's when the bankruptcy of Greek finances economically isolated the country (Petmezas 2013). In this economic and commercial depression and instability, financers had little willingness to invest in expensive and risky sponge campaigns, despite the fact they could be lucrative (Holmwood 1890). The number of hard-hat equipped sponge fishing boats inevitably decreased (Caravokyros 1895). In parallel, the increasing production of American sponges was a harsh competition for the coarser category of Mediterranean sponges (Holmwood 1890).

Subsequently, the beginning of the 20th century was marked by a massive emigration of Greeks searching for better life conditions (Maratou-Alipranti 1988). The Greek population lost 400000 migrants (Maratou-Alipranti 1988), their main destination being the United States. This destination, precisely Florida, was also chosen by sponge fishermen when in 1905, a hard-hat sponge fishing crew from Aegina (Greece) found unharvested commercial sponge beds in rather deep waters. By 1907, Mediterranean countries were progressively limiting hard-hat use, enhancing the departure of 1500 Greek fishermen using this equipment fleeing the Mediterranean Sea to exploit the sponge grounds around Tarpon Springs, Florida (Bucuvalas 2016). In this socio-economic situation, the Greek production remained rather low over the first half of the 20th century.

\section{Post World War II short sponge production revival}

During World War II, sponge fishing completely ceased in Greece. After the war, various conditions created a new favorable context for a substantial sponge production in Mediterranean waters. In 1947, the Dodecanese, that counted important sponge fishing islands such as Kalymnos and Symi, finally joined Greece after 375 years under Ottoman rule followed by 35 years of Italian domination (Paris Treaty). As a consequence, Greek sponge fishery regained strength, and sponge production in the first years following World War II was comparable to the most productive years of the 19th century. Post-war high production can also be imputed to the fact that sponge beds remained effectively unharvested by the Greek fleet during the five years of war and that new facilities were offered such as loans with low interests by the Greek Agricultural Bank. Moreover, the American rival sponge fishery was annihilated by a severe sponge disease outbreak related to a red tide event (Bernard 1972) that occurred in 1939 in Florida and the Gulf of Mexico waters. After war, the world sponge market turned again towards the Mediterranean Sea and the fishermen were available and able to satisfy the demand by a high production.

Although it is commonly accepted that Mediterranean sponges had been overexploited during the $19^{\text {th }}$ century (Pronzato and Manconi 2008; Voultsiadou et al. 2011), sponges were resilient and able to recover from this exploitation in the environmental context of the time. Between the 1880s and 1950, little had changed in the sponge fishing areas for Greece. The diving gear became lighter although hard-hat diving equipment was still used during the 1950s. The boats were more efficient, equipped with engines, but the fleet between 1883 and 1950 was reduced by two thirds (Apostolidès 1883). The slight warming of the temperature regime in $1940-1950$ (SST anomaly $+0,0579^{\circ} \mathrm{C}$ ) compared to $1880-1890$ (SST anomaly $-0,219^{\circ} \mathrm{C}$ ) did not seem to affect the sponge stocks, the Greek sponge fleet being able to produce circa 160 tons a year between 1947 and 1950 .

The combined effects of socio-economic and political changes during the second part of the 20th century

After 1950, Greek sponge production showed an overall negative trend until 1991, while annual production per boat remained comparatively high until the early 1970s. Also the fact that the production from the Greek waters recorded at the end of the 1970's was comparable to that of the late 1940's (Fig. 3) tends to indicate that the Greek sponge stocks generally supported the harvesting pressure during the third quarter of the 20th century. In the meantime, the thermal regime showed only little variation. Therefore, the sponge production decline observed between 1950 and 1970 
cannot be related to impacts of environmental change or to a decrease of fishing effort in response to first signs of overexploitation.

In fact, the Greek sponge fleet progressively decreased, first for socio-economic reasons. The majority of sponge fishermen originated from the islands of Limnos, Aegina, Hydra, Symi, Kastellorizo, Chalki, Kalymnos, the population of which either emigrated post-war (Kolodny 1966; Damer 2004), or turned towards other occupations such as seamanship in the developing merchant marine (Bernard 1976b), or in the tourism industry that offered steady income, with less expenses and better life conditions (Damer 2004). In the 1970's, only Trikeri, Limnos and Kalymnos islands continued to maintain a sponge fishing fleet, Kalymnos being responsible for about $74 \%$ of all the sponges harvested (Bernard 1976a).

In parallel, the second half of the 20th century was also marked by the development of the synthetic (artificial) sponges in Europe, this new product progressively replacing Mediterranean bath sponges in the industry as well as in domestic use (Bernard 1976b). This competition with synthetic sponges, also contributed to the abandonment and reduction of the sponge fishing activity in the Greek islands.

However, the most important factor explaining the decline of Greek fleet and of the sponge production before the 1970s was the reduction of their fishing area. During the first 15 years after the war, the harvested surface extended from Greece to Cyprus, Libya, Egypt, and Tunisia. It was subsequently progressively reduced to become restricted to Greece after 1972, with very occasional fishing around the islands of Lampedusa and Panteleria (Southern Italy) out of territorial waters. The 1953 incident illustrates the importance of this factor: that year, the low production was due to a combination of factors, the most significant being the ban of foreign sponge fishermen in Egypt and Libya early in the 1952 and 1953 seasons (Report of the prefecture of the Dodecanese, Online Resources 1). As at that time, Egypt and Libya were important sponge-fishing areas for Greek fishermen, Greek government deployed some efforts to resolve the problem, and managed to obtaining a five year agreement with Libya in 1954 (Olympitou 2014).

\section{The perverse effect of conflicting fishery policies}

In 1977, the sponge fishing fleet increased abruptly. Looking into more details, this increase came mainly from Kalymnos, a border island, where the number of boats sharply increased from 43 in 1976 to 68 in 1978 (Olympitou 2014). This can be attributed to the decision taken in July 1976 by the Greek Ministry of Economy to financially support replacement and modernization of fishing boats of border areas by guaranteeing $100 \%$ of the loans needed to do so. The annual production per boat started then to decrease, indicating overexploitation of the Greek sponge beds. At the end of the 1986 sponge fishing season, a disease outbreak hit sponges severely in the entire Mediterranean Sea (for a review see (Pérez and Vacelet 2014)), resulting the following years, in a constant decrease of the annual CPUEs until 1991. As a consequence of this poor productivity, in 1992, the number of sponge fishing boats dropped drastically in a single year. No doubt that the European program subsidising the destruction of fishing boats (2nd multi-annual EU Guidance Program to reduce fishing effort, 1987-1991), played a key role here. Boats that had been modernized and that had acquired new equipment 15 years before financed by the Greek government, were being destroyed and refunded in the early nineties. Thus, national and European fishing policies were conflicting over a short lapse of time, substantially impacting the sponge fishing effort and therefore the Greek production.

\section{The impacts of climate change}

Before World War II, yearly SSTs showed a slight oscillation but anomalies stayed mainly negative. During the same period, the Greek sponge exportations showed important fluctuations linked to a complex of factors previously detailed. The importance and the multiplicity of these socioeconomic drivers during this period, excludes any possibility to link sponge stock availability to 
thermal variations. However, the two highest periods of sponge production occurred during the decades 1880-90 and 1940-50 with different SST characteristics, the second showing a mean temperature $0.269^{\circ} \mathrm{C}$ higher than the first. In the 1950s, important quantities of sponges produced testified that large stocks existed in the Eastern part of the Mediterranean, underlining the resilience of commercial sponges and their ability to recover from overexploitation in the environmental context of the time.

The information concerning the disease outbreaks in Greek waters are scarce before 1986. In written documents, only Belloc (1948) indicated that sponges were periodically affected by disease outbreaks in limited areas such as in Crete for example. A fisherman interviewed in Kalymnos and one in Limnos recalled such an event also in the 1960s around Limnos Island, NE Greece.

During the years 1986-87, sponge beds were severely affected by epizootic outbreaks that impacted Greek and Mediterranean sponge production, and these events seemed to have their roots in the regional changing environment (Pérez and Vacelet 2014). This event has been quite well documented concerning the areas affected, but the cause of the disease was not clearly determined (Gaino et al. 1992; Vacelet, 1994; Pérez and Vacelet, 2014, Voultsiadou, 2011). Our long-term series shows that, during the 1980 decade, the annual Sea Surface Temperature anomalies of the Northern Hemisphere were still in the range of the past century variations. However, at regional scale, shorter series show that the Mediterranean SSTs increased of about $0.4^{\circ} \mathrm{C}$ per decade (Sakalli 2017) since the mid 1980's, and focusing on the Eastern basin SSTs underwent an increase of $1.1^{\circ} \mathrm{C}$ between 1985 and 2006 (Nykjaer 2009). The Mediterranean SST trends show an important spatial variability and should, therefore be considered at a sub-Mediterranean level, since different patterns of warming trends clearly appear (Pastor et al. 2018). Besides, at the Mediterranean scale, the warming rate in the last decade has accelerated compared to the period 1982-1992 of a factor 1.8 (Pastor et al. 2018). Furthermore, in addition to global change of the temperature regime, short term climate events are also known to trigger large scale disease outbreaks (for a review see Lejeusne et al. 2010).

All current Greek sponge fishermen witnessed that, since 1986, bath sponges are regularly affected by disease outbreaks that can locally induce very high mortality rates. Such outbreaks have also occurred in other Mediterranean areas, the causal link between the disease outbreaks and thermal anomalies being well supported by the most recent investigations (Pérez \& Vacelet 2014, Rivetti et al. 2014), and acidification of the sea might also be a factor affecting the sponges vitality (Goodwin and al. 2014). However, prior to conclude on a link between Greek sponge CPUE variability and thermal anomalies, monitoring at a higher geographical scale of seawater temperatures along with other physicochemical parameters need to be obtained.

Importance of the fishery and conservation aspects

In the Mediterranean, other sponge fishing populations exist, in Tunisia (Pérez and Vacelet 2014), Libya (Milanese et al. 2008) and Croatia (Rančić et al. 2010), but also throughout the world as in Florida, Cuba, the Bahamas and the Philippines for instance. A thousand-million-dollar investment for the revitalization of the sponging industry has recently started in the Bahamas, to "boost the local economy and decrease unemployment numbers” (Tribune 242, Wednesday, March 1st, 2017) testifying of the importance of this fishery in some insular communities.

Maintaining the diversity of small-scale Mediterranean fisheries is essential, especially when they are culturally anchored in economically fragile insular societies. However, management policies need to be coherent between the national and the European levels, and must take into account the specificities of each small-scale fishery. In Greece, some conservation measures already exist such as the delimitation of no-take zones or the definition of a minimum individual catch size (Greek Fishery Regulation, 1970, article 102), but they are not always respected. We believe that adapted and feasible measures should be considered and discussed with the sponge professionals. Fishermen should be involved in an efficient long-term management program that would accurately survey the 
target species, their distribution (depth and habitat), and their catch size as well as take in consideration the fishermen's subsistence in the context of a changing Mediterranean climate. They have already adapted to the uncertain availability of the resource, by reducing their crew and targeting other species during the winter period. Nowadays, the overall production remains low but the CPUEs are high and show a positive trend, although inter-annually variable. The reduced CPUEs of the last three years (2015-2017) can be attributed to the fact that fishermen get a steady income from holothurian fishing and therefore have reduced the time spent on fishing sponges. The low sponge production, the high CPUEs and the adaptability of the sponge fishermen indicate that sponge fishing in Greece in the actual situation is sustainable.

\section{Conclusion}

Reconstruction of the sponge production over 150 years allows to put in perspective the actual situation. The Greek production is nowadays historically low. During the $19^{\text {th }}$ and the beginning of the $20^{\text {th }}$ century, the main drivers of the Greek sponge production were the market demand and the economic situations of the producing and importing countries. Although the pressure was high on the stocks, the sponge populations were resilient enough to allow a new production peak during the mid- $20^{\text {th }}$ century, in a slightly warmer thermal context. The decrease of the production since 1950 can mainly be attributed to: (i) to a decrease of the fishing effort consecutive to a shrinking fishing area and a loss of interest in the fishery between 1950 and the 1970s, (ii) to overexploitation with an increased fishing pressure on a restricted fishing area between 1977 and 1991, and (iii) to the 1986 epizootic outbreak that led sponge fishermen to destroy for refund the majority of the boats. After the 1986 epizootic consequences on the fishery, only few boats remained active and they decreased their crew to maintain a certain profitability. Since then, repeated disease outbreaks have weakened the bath sponge resources of the Greek seas that appeared to have lost their resilience and have leaded to a contraction of the depending populations of fishermen.

Thus, compared to a few decades ago, fishing pressure on sponges has much reduced and CPUEs are high, but the uncertainties of the stock availability oblige sponge fishermen to diversify their targets. Therefore, in Greece nowadays, the fishery should perhaps not be considered by its target (sponge fishing) but by the fishing mean used (diving) in order to ensure the sustainability of the fishery as well as the conservation of their various target species. Target diversification of this diving population lessens the pressure on sponges, therefore should be encouraged but controlled.

\section{Acknowledgments}

Funding: This work is part of the SACOLEVE program which is a contribution to Labex OTMed ( ${ }^{\circ}$ ANR-11-LABX-0061) and has received funding from Excellence Initiative of AixMarseille University - A*MIDEX, a French "Investissements d'Avenir” programme”. The SACOLEVE program has also received funding from the CNRS INEE BIODIVMEX (MISTRALS) program and from CNRS INEE Exploratory projects (PEPS Blanc 2016). General: The authors warmly thank J. Vacelet and P. Chevaldonné for the fruitful discussions and comments on the manuscript. Author contributions: D.F. and T.P. conceived and coordinate the SACOLEVE program. M.F. and D.F. collected the data, and all authors contributed to the discussion of the results. M.F. and T.P. prepared the draft of the manuscript, and all authors contributed to its final writing. Conflict of Interest: The authors declare that they have no conflict of interest. 


\section{References}

Apostolidès NC (1883) La Pêche en Grèce. Ichthyologie, migrations, engins et manières de pêche, produits, statistique et législation, Typographie de Perris frères. Athènes

Barange M, Merino G, Blanchard JL, Scholtens J, Harle J, Allison E.H, Allen J.I, Holt J, Jennings S (2014) Impacts of climate change on marine ecosystem production in societies dependent on fisheries. Nat Clim Change 4:211-216. doi: 10.1038/nclimate2119

Belloc G, (1948) Inventory of the fishery resources of Greek waters. UNRRA-FAO 213, Athens.

Bernard HR (1972) Sponge fishing and technological change in Greece. In: Bernard HR, Pelto JP (eds) Technology and social change, Macmillan. New York, pp 167-206

Bernard HR (1976a) Kalymnos: The Island of the Sponge Fishermen. Ann N Y Acad Sci 268:291-307

Bernard HR (1976b) Sponge markets of Kalymnos. Anthropologica 18:81-96

Biliotti A (1873) Rhodes. Report by acting Vice-Consul Biliotti N`550. In: Reports from her Majesty’s consuls on

the British trade abroad. Part 1, Harrison and sons. Foreign Office, London, pp 44-47

Blondel E (1840) Deux ans en Syrie et en Palestine (1838-1839), Librarie P. Dufart. Paris

Brierley AS, Kingsford MJ (2009) Impacts of Climate Change on Marine Organisms and Ecosystems. Curr Biol 19:R602-14. doi: 10.1016/j.cub.2009.05.046

Bucuvalas T (2016) Greeks in Tarpon Springs. Arcadia Publishing, Charleston, U.S.A.

Caravokyros M (1895) Etude sur la pêche des éponges. Les pays spongifères de l’Empire et le scaphandre.

Képhalidès, Constantinople

Cheung WW, Watson R, Pauly D (2013) Signature of ocean warming in global fisheries catch. Nature 497:365. doi: 10.1038/nature12156

Coll M, Piroddi C, Steenbeek J, Kaschner K, Ben Rais Lasram F, Aguzzi J, Ballesteros E, Bianchi CN, Corbera J, Dailianis T, Danovaro R, Estrada M, Froglia C, Galil BS, Gasol JM, Gertwagen R, Gil J, Guilhaumon F, KesnerReyes K, Kitsos MS, Koukouras A, Lampadariou N, Laxamana E, López-Fé de la Cuadra CM, Lotze H.K, Martin D, Mouillot D, Oro D, Raicevich S, Rius-Barile J, Saiz-Salinas J. I, San Vicente C, Somot S, Templado J, Turon X, Vafidis D, Villanueva R, Voultsiadou E (2010) The Biodiversity of the Mediterranean Sea: Estimates, Patterns, and Threats. PLoS one 5:1-36. doi: 10.1371/journal.pone.0011842

Damer S (2004) Signifying Symi: setting and performance on a Greek island. Ethnography 5:203-228. doi: $10.1177 / 1466138104044374$

FAO (2016) The State of Mediterranean and Black Sea Fisheries. FAO, Rome, Italy

FAO (2018) FAO Yearbook Fishery and Aquaculture Statistics 2016. Capture production. FAO, Rome, Italy Gaino E, Pronzato R, Corriero G, Buffa P (1992) Mortality of commercial sponges: Incidence in two Mediterranean areas. Ital J Zool 59: 79-85. doi:10.1080/11250009209386652

Goodwin C, Rodolfo-Metalpa R, Picton B, Hall-Spencer JM (2014) Effects of ocean acidification on sponge communities. Mar Ecol 35: 41-49. doi: 10.1111/maec.12093

Hanich Q, Wabnitz CC, Ota Y, Amos M, Donato-Hunt C, Hunt A (2018) Small-scale fisheries under climate change in the Pacific Islands region. Mar Policy 88:279-284. doi: 10.1016/j.marpol.2017.11.011

Harley CD, Hughes AR, Hultgren K, Miner BG, Sorte CJG, Thornber CS, Rodriguez LF, Tomanek L, Williams SL (2006) The impacts of climate change in coastal marine systems. Ecol Lett 9:228-241. doi: 10.1111/j.14610248.2005.00871.x

Henrichs M.P (1836) Archives du Commerce et de l'industrie agricole et manufacturière, répertoire des chambres de commerce, chambres consultatives des arts et manufactures et des Tribunaux de Commerce. Paris.

Holmwood F (1890) Turkey. Report for the year 1889 on the trade of Smyrna $N^{\circ} 764$. In: Diplomatic and consular reports on trade and finance, Harrison and sons. Foreign Office, London, pp 1-15

Kennedy JJ, Rayner NA, Smith RO, Parker DE, Saunby M (2011a) Reassessing biases and other uncertainties in sea surface temperature observations measured in situ since 1850: 1 . Measurement and sampling uncertainties. J Geophys Res Atmos 116. doi: 10.1029/2010JD015218

Kennedy JJ, Rayner NA, Smith RO, Parker DE, Saunby M (2011b) Reassessing biases and other uncertainties in sea surface temperature observations measured in situ since 1850: 2. Biases and homogenization. Journal of Geophys Res Atmos 116. doi: 10.1029/2010JD015220

Kolodny Y (1966) La population des Iles en Méditerranée. Méditerranée 7:3-31. doi: 10.3406/medit.1966.1186 Lejeusne C, Chevaldonné P, Pergent-Martini C, Boudouresque CF, Pérez T (2010) Climate change effects on a miniature ocean: the highly diverse, highly impacted Mediterranean Sea. Trends Ecol Evol 25:250-260.

doi:10.1016/j.tree.2009.10.009

Maratou-Alipranti L (1988) Courants migratoires en Grèce mouvement de rapatriement des Grecs réfugiés politiques. In: Les Migrations Internationales. Problèmes de mesure, évolutions récentes et efficacité des politiques. Association internationale des démographes de langue française, Calabre, Italie, pp 181-190 
Maynou F, Morales-Nin B, Cabanellas-Reboredo M, Palmer M, García E, Grau AM (2013) Small-scale fishery in the Balearic Islands (W Mediterranean): a socio-economic approach. Fish Res 139:11-17. doi:

10.1016/j.fishres.2012.11.006

Milanese M, Sarà A, Manconi R, Abdalla AB, Pronzato R (2008) Commercial sponge fishing in Libya: historical records, present status and perspectives. Fish Res 89:90-96. doi: 10.1016/j.fishres.2007.09.018

Nykjaer L (2009) Mediterranean Sea surface warming 1985-2006. Clim Res 39:11-17. doi: 10.3354/cr00794

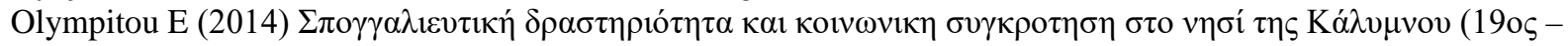
20 o $\alpha_{1 .}$.) (Sponge Fishery Activity and Social Formation in Kalymnos Island, 19th-20th Century.). Ethniko Idrima Erevnon, Athens

Pastor F, Valiente JA, Palau JL (2018) Sea surface temperature in the Mediterranean: Trends and spatial patterns (1982-2016). Pure Appl Geophys 175: 4017-4029. doi: 10.1007/s00024-017-1739-z

Pérez T, Vacelet J (2014) Effect of Climatic and Anthropogenic Disturbances on Sponge Fisheries. In: The Mediterranean Sea: its history and present challenges, Springer, Dordrecht, Netherlands. pp 577-587

Petmezas SD (2013) L’économie agricole grecque face à la longue crise de la première globalisation. The Historical Review/La Revue Historique 10:85-106. doi: 10.12681/hr.307

Pronzato R, Manconi R (2008) Mediterranean commercial sponges: over 5000 years of natural history and cultural heritage. Mar Ecol 29:146-166. doi: 10.1111/j.1439-0485.2008.00235.X

Rančić IP, Petrić M, Bakran-Petricioli T (2010) The current state of sponge fishing in the Republic of Croatia. In: Uriz MJ, Maldonado M, Becero M, Turon X (eds) Book of Abstracts of 8th World Sponge Conference: Ancient animals-New Challenges (8th WSC). pp 289-289

Rivetti I, Fraschetti S, Lionello P, Zambianchi E, Boero F (2014) Global warming and mass mortalities of benthic invertebrates in the Mediterranean Sea. PLoS one 9. doi: 10.1371/journal.pone.0115655

Sakalli A (2017) Sea surface temperature change in the Mediterranean Sea under climate change: a linear model for simulation of the sea surface temperature up to 2100. Appl Ecol Env Res 15:707-716. doi:

10.15666/aeer/1501_707716

Tsikliras AC, Dinouli A, Tsiros V-Z, Tsalkou E (2015) The Mediterranean and Black Sea Fisheries at Risk from Overexploitation. PLoS one 10:e0121188. doi: 10.1371/journal.pone.0121188

Tzanatos E, Raitsos DE, Triantafyllou G, Somarakis S, Tsonis AA (2014) Indications of a climate effect on Mediterranean fisheries. Clim Change 122:41-54. doi: 10.1007/s10584-013-0972-4

Vacelet J (1994) The struggle against the epidemic which is decimating Mediterranean sponges. FAO, technical report.

Voultsiadou E, Dailianis T, Antoniadou C, Vafidis D, Dounas C, Chintiroglou CC (2011) Aegean bath sponges: historical data and current status. Rev Fish Sci 19:34-51. doi: 10.1080/10641262.2010.531794

\section{Figures and Tables}



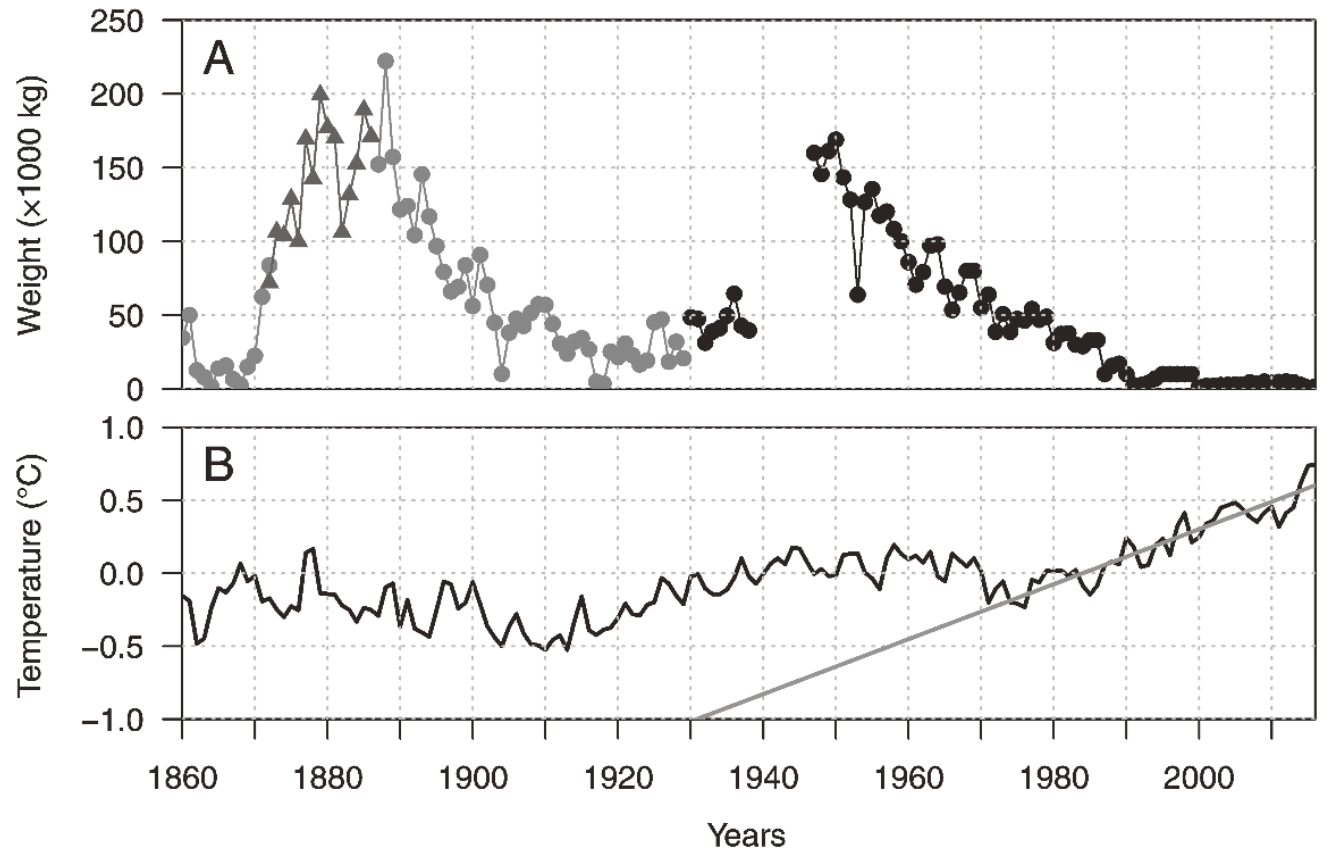

Fig. 1: Greek sponge production/exportation variations compared to annual average of sea surface temperature (SST) anomalies of the Northern hemisphere between 1860 and 2017. A, annual Greek bath sponge exportation (grey dots), production (black dots) and exportation to Trieste (dark grey triangles). B, annual average of sea surface temperature (SST) anomalies of the Northern Hemisphere with 1961-1990 reference period and trend for the years 1987 to 2017 (grey).

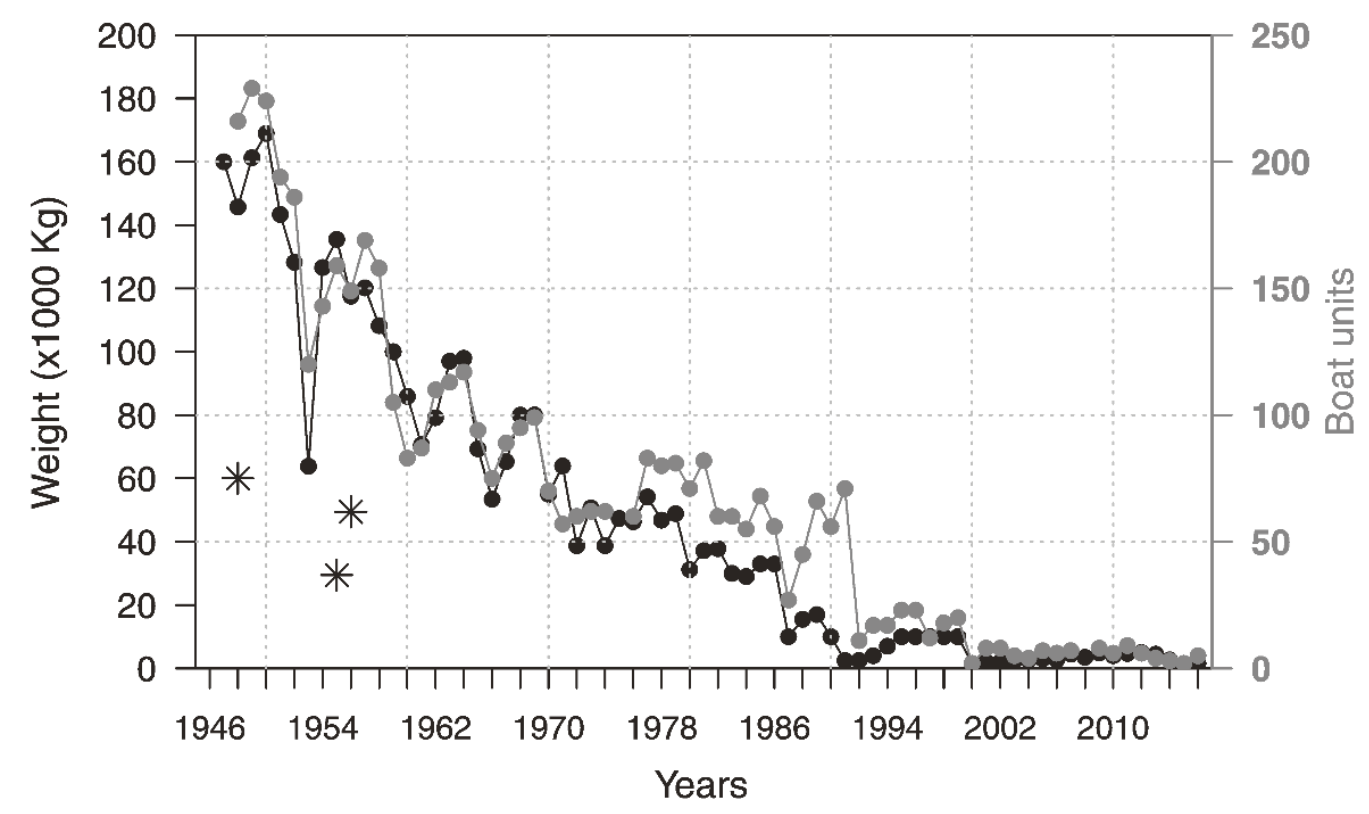

Fig. 2: Annual Greek sponge production (black) and number of sponge fishing boats (grey) after World War II. Stars represent production coming from Greek seas sensu stricto (see text) for the given years. 


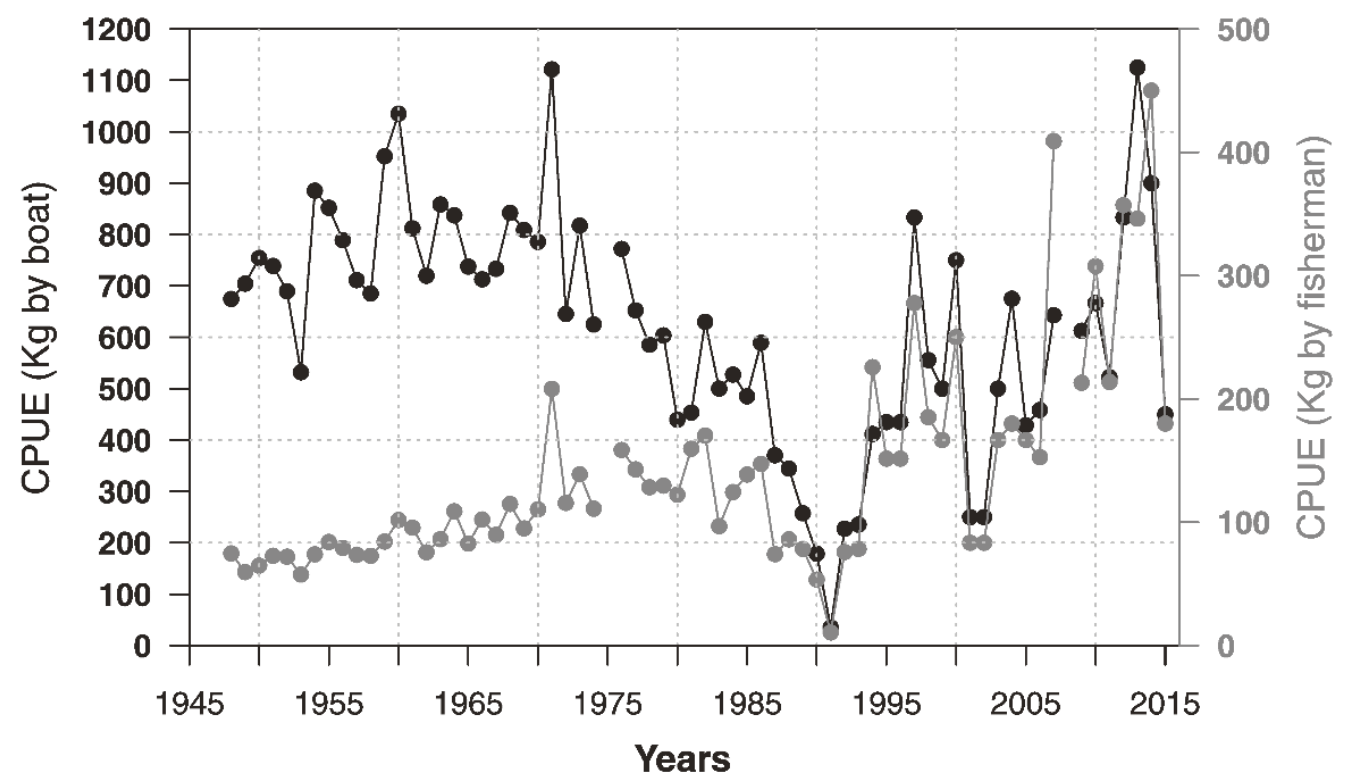

Fig. 3 Greek annual catch per unit effort (CPUE) after World War II represented by two metrics. Black curve represents the CPUE by boat, the grey curve the CPUE by fisherman. 